\title{
Energy Efficiency Contrivances Under Aspects of Climate Change Mitigation in Thermal Power Plants
}

\author{
Gullipalli Rudra Narsimha Rao*, Rahul Raju Dusa \\ Industrial Energy Group, The Energy and Resources Institute (TERI), Bangalore, India
}

\section{Email address:}

grnrao@teri.res.in (G. R. N. Rao)

${ }^{*}$ Corresponding author

\section{To cite this article:}

Gullipalli Rudra Narsimha Rao, Rahul Raju Dusa. Energy Efficiency Contrivances Under Aspects of Climate Change Mitigation in Thermal Power Plants. International Journal of Energy and Power Engineering. Vol. 7, No. 3, 2018, pp. 33-39. doi: 10.11648/j.ijepe.20180703.12

Received: July 10, 2018; Accepted: July 27, 2018; Published: August 22, 2018

\begin{abstract}
The COP-21 meeting in Paris achieved a key milestone of climate change negotiations, leading to inception of essential mitigation actions pledged by all the developed and developing countries. It is advocated to stabilize the global temperature at $2^{\circ} \mathrm{C}$ above the pre-industrial levels by 2100 . All countries are compelled to take much stronger action. India ranks $3^{\text {rd }}$ position in carbon dioxide emissions on global scale. India has committed a reduction in the emissions intensity of GDP by $33 \%$ to $35 \%$ from 2005 levels by 2030 . India's commercial energy use in industrial sector is close to $50 \%$ and contributes to highest emissions across various sectors. To enhance energy efficiency in energy-intensive large industries, a novel market based mechanism action programme called Perform, Achieve and Trade (PAT) has been developed. PAT mechanism is time bound with periodic cycle of three years. PAT cycle I has achieved an annual energy savings of 8.67 mtoe from 478 energy intensive industries with a total annual energy consumption of 165 mtoe. Thermal power plants (144 numbers) account to large share of annual energy consumption i.e. $63.3 \%$. The paper highlights actions taken by three different power plants (coal, natural gas, and fuel oil) to achieve their individual set target under PAT mechanism. Various energy conservation measures implement by these power plants are deliberated. The learning's from energy conservation measures implemented in these power plants can be easily replicated (or) reviewed for similar thermal power plants internationally. These measures may also be included under mitigation actions of other nations to realize emissions reduction.
\end{abstract}

Keywords: Carbon Dioxide Emissions, Climate Change, Energy Conservation, PAT Cycle, Thermal Power Plants

\section{Introduction}

It is known that the Earth's climate has changed throughout history. However, the warming trends, since the mid-20th century are a result of human activity (greater than $95 \%$ probability), and scientists were able to say with conviction that the industrial revolution, which propagated the use of conventional sources of fuels, is largely responsible for global warming [1]. In 2015, the historic Paris Agreement marks the latest step in the evolution of the UN climate change (CC) regime and builds on the work undertaken under the UNFCCC while charting a new course in the global effort to combat climate change [2]. Each country thereby committed itself to take action to mitigate emissions up to 2030 as outlined in their Intended Nationally Determined Contributions (INDCs).
If all countries deliver on what they have promised by 2030 and progress thereafter continuing at the same rate global temperature is likely to be more than $3^{\circ} \mathrm{C}$ above pre-industrial levels by 2100 [3]. The envisioned target is to keep global temperature rise below $2{ }^{\circ} \mathrm{C}$ pre-industrial levels required Global Greenhouse Gas (GHG) emissions reduction [4]

India was one of the signatories of Paris agreement and its INDCs covered three areas [5]

i. A reduction in the emissions intensity of GDP by 33 to $35 \%$ from 2005 levels by 2030 ;

ii. An increase in non-fossil-fuel based electricity capacity from $12 \%$ of total capacity in $2014 / 15$ to $40 \%$ by 2030 ;

iii. Increasing forest cover to absorb 2.5 to 3 billion tonnes of $\mathrm{CO}_{2}$ by 2030 ;

With the goal of reducing energy intensity of the Indian economy, Ministry of Power through Bureau of Energy Efficiency (BEE) has initiated a number of energy efficiency 
initiatives. The National Mission for Enhanced Energy Efficiency (NMEEE) aims to strengthen the market for energy efficiency by creating a conducive regulatory and policy regime. It pursues to unlock the market for energy efficiency to enable achieving total avoided capacity addition of 19,598 MW and fuel savings of around 23 million tonnes per year at its full implementation stage [6].

Under NMEEE, one such initiative in place to enhance energy efficiency.is Perform, Achieve and Trade (PAT) scheme for industrial sector. PAT as a market based energy efficiency trading mechanism, which covered 478 industries (Designated Consumers, DC) in eight energy-intensive industrial sectors (Aluminium, Cement, Chlor-Alkali, Fertilizer, Iron and Steel, Paper and Pulp, Textile and Thermal Power Plants) during the first cycle, accounting for one-third of total energy consumption in the country. [7] The mandated decrease in the specific energy consumption under PAT programme has led to a decline of 4 to $5 \%$ in their specific energy consumption in 2015 as compared to that in 2012.[8] Energy Saving Certificates (ESCerts) are issued to consumers who over-achieved their individual set target. The scheme has been further widened and deepened to include additional sectors like railways, electricity distribution companies and refineries in the next cycle and would cover more than half the commercial energy consumed in India.

India is the world's $6^{\text {th }}$ largest producer of power (electricity) [9]. Thermal power plants as been ranked as number one designated consumer by BEE with respect to total energy consumption. [10] The ranking of the most important designated consumer sectors with respect to their energy consumption and energy costs is given below in table 1 .

Table 1. Energy consumption and energy cost ranking for the energy intensive sectors of DCs.

\begin{tabular}{llll}
\hline Sector & $\begin{array}{l}\text { Energy } \\
\text { intensity Rank }\end{array}$ & $\begin{array}{l}\text { Percentage of } \\
\text { energy costs Rank }\end{array}$ & $\begin{array}{l}\text { Total energy } \\
\text { consumption Rank }\end{array}$ \\
\hline Power & 2 & 1 & 1 \\
Fertilizer & 1 & 3 & 2 \\
Steel & 5 & 5 & 4 \\
\hline
\end{tabular}

There are 144 DCs in the thermal power sector. The DCs in this sector are categorized based on the type of fuel consumed i.e. coal, lignite, natural gas and diesel (fuel oil). Coal/lignite based DCs are highest at 107 in numbers followed by natural gas based and diesel based DCs at 33 and 4 numbers respectively. The distribution of the DCs in the thermal power sector is given in the following figure 1 .

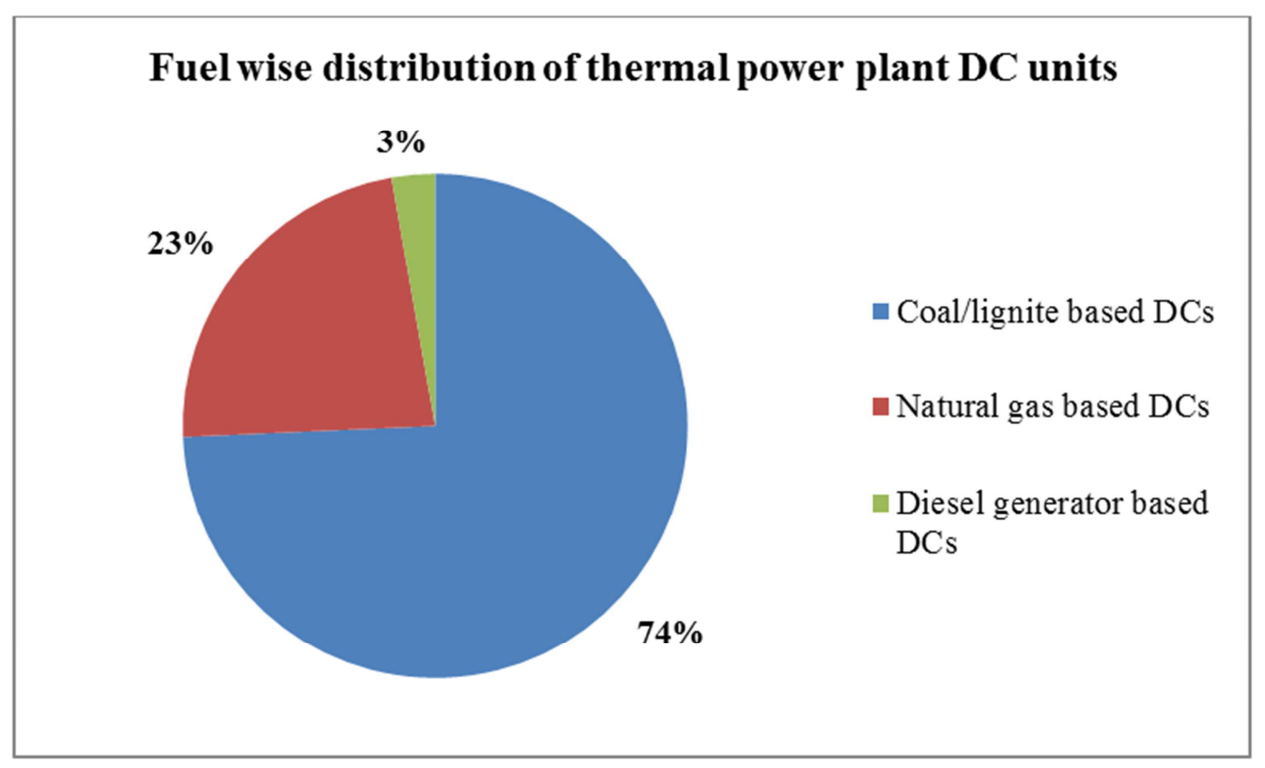

Figure 1. Fuel wise distribution of thermal power plant DC units in PAT-I cycle.

The assessed energy consumption of thermal power plants is 104.5 million mtoe per annum. Thermal power sector was identified as the most important sector with potential contribution of 3.211 million mtoe per annum energy savings representing $48 \%$ of the overall PAT target [11]. The target (energy saving to be achieved) for individual thermal power plants (as DC) were established based on the defined heat rate with reference to the baseline period operational heat rate and deviation from the designed heat rate.

\section{Methodology}

The notified listed of designated consumers (478 numbers) are subjected to filing of annual energy returns in mandated Form 1 to the state designated agency (SDA) and the BEE. It is a mandatory reporting process where each power plant has to submit their details on energy consumption (input fuel), auxiliary power consumption as well as export power to grid. The DC gets a baseline energy audit conducted by entrusting an accredited energy auditor, who verifies the submitted energy data, establishes gate-to-gate concept (GtG), collects further more technical information like efficiency and energy performance of major equipment, process and subsystems inside plant boundary etc. For the thermal power sector, the Specific Energy Consumption (SEC) has been specified based on the deviations of the average net heat rate of the 
three years (2007 to 2010) i.e. baseline period from the designed net heat rate as shown in the following table 2 .

Table 2. Target setting Calculation - Thermal power plants.

\begin{tabular}{lll}
\hline $\begin{array}{l}\text { Deviation in Net } \\
\text { Station Heat Rate from } \\
\text { Design Net Heat Rate }\end{array}$ & $\begin{array}{l}\text { Reduction Target for \% } \\
\text { deviation in the Net } \\
\text { Station heat Rate }\end{array}$ & $\begin{array}{l}\text { \% Reduction } \\
\text { Target in Net } \\
\text { Station Heat Rate }\end{array}$ \\
\hline$\leq 5 \%$ & $10 \%$ & $0.5 \%$ \\
$>5 \%$ and $\leq 10 \%$ & $17 \%$ & $0.85 \%$ to $1.7 \%$ \\
$>10 \%$ and $\leq 20 \%$ & $21 \%$ & $2.1 \%$ to $4.2 \%$ \\
$>20 \%$ & $24 \%$ & $4.8 \%$ and above \\
\hline
\end{tabular}

In the ensuing PAT scheme, thermal power plants will be required to achieve a reduction of Specific Energy Consumption (SEC) from their baseline SEC within 3 years' time (2011-12 to 2013-14 for PAT cycle - I). As per PAT consultation process it is important step to verify the submitted energy consumption (input fuel), energy produced, internal energy consumption and energy export to derive specific energy consumption (SEC) achieved by thermal power plant. The process involves verifying the energy performance of DCs considering normalization and other relevant factors as defined by the PAT rules. [12]

A sample calculation for target setting based on the energy consumption, energy generation and heat rate details is illustrated in table 3 .

\begin{tabular}{|c|c|}
\hline Station installed capacity & 840 \\
\hline $\begin{array}{l}\text { Station Gross Design Heat Rate (Design } \\
\text { GHR)) }\end{array}$ & $2386 \mathrm{kcal} / \mathrm{kWh}$ \\
\hline \multicolumn{2}{|l|}{ Last 3 years average $(2007-2010)$} \\
\hline \multicolumn{2}{|l|}{ Station Gross Generation } \\
\hline \multicolumn{2}{|l|}{ Station Net Generation } \\
\hline Auxiliary Power Consumption (APC) & $8.16 \%$ \\
\hline Operating Gross Heat Rate (GHR) & $\mathrm{cal} / \mathrm{kWh}$ \\
\hline Operating Net Heat rate (NHR) & $1 / \mathrm{kwh}$ \\
\hline \multirow{2}{*}{ Net Design heat rate (Design NHR) } & {$\left[\frac{2386}{(1-0.816)}\right]=2598$} \\
\hline & $\begin{array}{l}{[(1-0.816)]} \\
\mathrm{kcal} / \mathrm{kWh}\end{array}$ \\
\hline Deviation in Net Operative heat rate & $\begin{array}{l}2739-2598=141 \\
\mathrm{kcal} / \mathrm{kWh}\end{array}$ \\
\hline Percentage deviation from design NHR & {$\left[\frac{141}{0 \Gamma 00}\right] \times 100=5.43 \%$} \\
\hline Target Reduction & $\begin{array}{l}{[\overline{2598}] \times 100=3.43 \%} \\
5.43 \times 0.17=0.923 \%\end{array}$ \\
\hline \multicolumn{2}{|c|}{$\begin{array}{l}\text { (for deviation more than } 5 \% \text { in Net operating Heat Rate from Design Heat } \\
\text { Rate: } 17 \% \text { deviation) }\end{array}$} \\
\hline Net Design heat rate (Design NHR) & $\mathrm{cal} / \mathrm{kWh}$ \\
\hline Target Reduction in Net heat rate & $\begin{array}{l}{\left[\frac{0.923}{100}\right] \times 2598=24} \\
\mathrm{kcal} / \mathrm{kWh}\end{array}$ \\
\hline Target for Net Heat Rate & $\begin{array}{l}2739-24=2715 \\
\mathrm{kcal} / \mathrm{kWh}\end{array}$ \\
\hline Station Net Generation & $5982 \mathrm{MU}$ \\
\hline $\begin{array}{l}\text { Target reduction in metric tonnes of oil } \\
\text { equivalent (mtoe) }\end{array}$ & $\frac{5982 \times 106 \times 24}{104 \times 103}=14358 \mathrm{MT}$ \\
\hline
\end{tabular}

\section{Profile of Thermal Power Plants}

The power sector is a key driver of global energy growth, and the only sector where all the primary fuels compete. Total electricity consumption will be $61 \%$ higher in 2030 than in 2011, growing by $2.5 \%$ per annum (p.a). [13] It is expected to shift in change of fuel usage for power generation regionally.

Case study of three different input fuel based thermal power plants are discussed in this paper. The salient features of these power plants are highlighted in the following sections.

\subsection{Coal Based Power Plant}

The power plant consists of boiler and turbine Unit of 63.5 MW rated capacity. Plant uses pulverized coal using four ball mills. Boiler is also installed with furnace oil supporting system for emergency use as well as for start-up. Plant uses both imported and Indian coal. Blending is carried out at coal transmission belt after coal reclamation. Plant maintains blend ratio of 5:1 (Indian: Imported). Plant has installed four bunkers of each $239 \mathrm{~m}^{3}$ capacity connected with individual mills. Coal consumption during full load power generation is about 55 TPH maximum.

Boiler produces steam at $275 \mathrm{TPH}, 510^{\circ} \mathrm{C}$ temperature and $90 \mathrm{~kg} / \mathrm{cm}^{2}$ pressure. Generated steam is passed through Steam Turbine Generating (STG) Unit of 63.5 MW rated capacity. The steam turbine of single cylinder, no reheat, condensing type is designed to operate with steam at 88 $\mathrm{kg} / \mathrm{cm}^{2}, 507^{\circ} \mathrm{C}$. The designed speed of turbine is $3000 \mathrm{rpm}$ and is suitable for continuous operation at Maximum Continuous Rating (MCR) output in the frequency band of $+5 \%$ to $-3 \%$ of $50 \mathrm{~Hz}$ without any limitation. The steam turbine has control system of electrohydraulic type. The generated power is used for its captive business (through wheeling \& banking) and close to $40 \%$ exported to grid.

\subsection{Natural Gas Based Power Plant}

The Power plant is a Combined Cycle Power Plant (CCPP) with installed capacity of $119.8 \mathrm{MW}$, and export power to the state power grid. The Natural Gas (about 5,00,000 $\mathrm{sm}^{3}$ per day) for the power generation is supplied at the plant boundary, through a dedicated pipeline by a gas company. The power plant has been designed to operate with a very little quantity of water as compared to any conventional power plants. This is made possible through the use of aircooled condensers against the normal practice of watercooled condensers. The plant requires minimal quantity of water as make-up in steam generating circuit. Gas turbine is provided with Dry Low NOx combustors, which produces low NOx level in the flue gases. The power plant ensures steady and uninterrupted supply of power to grid, based on natural gas availability.

\subsection{Fuel Oil Based Power Plant}

The power plant consists of four low speed diesel generating sets of $51.48 \mathrm{MW}$. Each engine is installed with waste heat recovery boiler (WHRB) to produce steam. The Power plant has been designed to operate as a base load power station and the installed four diesel engines operate on residual Low Sulphur Heavy Stock (LSHS) as a fuel. Light Diesel Oil (LDO) is used during the plant start-up and shut down. 
The high temperature exit gas of engine is passed through waste heat recovery boilers connected to each engine. Out of four WHRB during normal operation two units will be in line to generate steam required for other auxiliary process (like LSHS pre heating, vapour absorption machines etc.,). The plant make-up cooling water requirement is meeting by treating municipal sewage, a separate water treatment plant of $7,200 \mathrm{~m}^{3} /$ day capacity installed inside the plant premises.

\section{Implemented Energy Conservation Measures}

This particular section emphasized on above three thermal power plants operations and realized energy savings through implementation of energy conservation measures during PAT cycle period.

\subsection{Coal Based Thermal Power Plant}

The power plant is in commercial operation since 1999. The company ensures steady and uninterrupted supply of power to grid on continuous basis. The power plant operational load factor reduced from 92 to $86 \%$ during PAT cycle I, it is mainly due to grid restrictions in evacuation in power generated from plant. The power plant auxiliary power consumption reduced from 9.7 to $9.2 \%$, even at reduced plant load factor. Plant operational net heat rate is reduced by $3.2 \%$ from its baseline after implementation of various energy conservation measures.

i. Coal is the main fuel for the power plant. Both Indian and imported coal is used during the baseline period and assessment year. Combined coal consumption with weighted average gross calorific value $(\mathrm{GCV})$ is used for heat rate calculations. Plant maintained uniform GCV of coal for power plant operations by procuring higher caloric value fuel at premium cost. The plant utilized combined coal quantity, its GCV and operating heat rates are given in table 4 .

Table 4. Coal consumption, GCV and operating heat rates of the referred $D C$.

\begin{tabular}{|c|c|c|c|c|c|}
\hline Particulars & Unit & Baseline & 2012-13 & 2013-14 & 2014-15 \\
\hline Coal & & & & & \\
\hline $\begin{array}{l}\text { Coal } \\
\text { consumption }\end{array}$ & MT & 407679.592 & 390705.498 & 397701.64 & 374774.8 \\
\hline GCV Of Coal & $\mathrm{kCal} / \mathrm{Kg}$ & 4087.89 & 4041.72 & 4067.83 & 4022.29 \\
\hline $\begin{array}{l}\text { Plant Gross } \\
\text { Heat Rate }\end{array}$ & $\mathrm{kCal} / \mathrm{kWh}$ & 3250.00 & 3176.66 & 3108.21 & 3161.02 \\
\hline $\begin{array}{l}\text { Plant Net Heat } \\
\text { Rate }\end{array}$ & $\mathrm{kCal} / \mathrm{kWh}$ & 3598.00 & 3483.37 & 3401.10 & 3482.42 \\
\hline
\end{tabular}

ii. Air preheater (APH) direction of rotation has been changed (i.e. first primary air then secondary air). The monitored rise in air temperature near APH outlet after rotation change of primary and secondary air is $8^{\circ} \mathrm{C}$ and $4^{\circ} \mathrm{C}$ respectively. This resulted in reduction of $\mathrm{APH}$ leakage from $16 \%$ to $7 \%$ after modification. The reduction of leakage also led into reduction in Primary air fans power consumption. iii. Induced draft (ID) fans connected inlet guide vanes (IGV) center flap split shafts were replaced with new split shafts. The measured reduction in power consumption across ID fans is $33 \mathrm{~kW}$.

iv. Implementing recycle boiler blow down water and installing water treatment plant (WTP) for effluent treatment from neutralization pit, resulted into reduction in operation of bore wells as well significant reduction in chemical consumption near DM plant.

\subsection{Natural Gas Based Thermal Power Plant}

The combined cycle gas power plant is in commercial operation since August 2005. The power plant has been designed to operate with a very less quantity of water as compared to any conventional power plants. This is made possible through the use of air-cooled condensers against the normal practice of water-cooled condensers. The plant requires minor quantity of water as make-up in steam generating circuit. Gas turbine is provided with Dry Low NOx combustors, which produces low NOx level in the flue gases. Generating station has been operated at different plant load factors (PLF) depending on natural gas availability. Plant load factor and plant availability factor is $56.49 \%$ and $93.87 \%$ respectively during the assessment year. The plant gross operating heat rate is $2141 \mathrm{kcal} / \mathrm{kWh}$. The plant's operating auxiliary power consumption is $5.48 \%(32.475$ $\mathrm{MU})$, taking into account same operative net plant heat rate is $2265 \mathrm{kcal} / \mathrm{kWh}$. Plant operational net heat rate is reduced by $1.3 \%$ from its baseline accounting correction factor for PLF. However plant focused in reduction of auxiliary power consumption through investments (refer table 5) and exceeded its PAT scheme commitments.

Table 5. Auxiliary power consumption comparison between baseline period and assessment year.

\begin{tabular}{lll}
\hline Section / Equipment & Baseline & Assessment \\
\hline Plant Generation Load, MW & $62+47: 109$ & $40+25: 65$ \\
Natural gas Booster Compressor, kW & 1511 & 1439 \\
Boiler feed Water pump, kW & 1040 & 488 \\
ACC (14 Nos), kW & 1022 & 1021 \\
ACHE (16 no's), kW & 102 & 92 \\
CCW pump, kW & 67 & 70 \\
ACW Pump, kW & 52 & 53 \\
CEP, kW & 146 & 64 \\
Compressor (on load), kW & 52 & 20 \\
Lighting, kW & 20 & 20 \\
LT Drives ( Motors 11kW, AC load etc.), kW & 500 & 310 \\
Transformer +bus bar Losses (measured), kW & 500 & 465 \\
Unaccounted losses (Balance), kW & 488 & 52 \\
Total auxiliary Load, kW & 5500 & 4095 \\
\hline
\end{tabular}

Energy conservation measures incorporated to achieve reduction in the auxiliary power consumption are listed as follows:

i. Normal operation one boiler feed pump is in continuous use. The measured water flow rate $(170$ $\mathrm{TPH}$ ) from the pump was $89.5 \%$ of the design pump capacity (190 TPH). It was observed that feed water pump delivery line valves are throttled before drum. 
The monitored pressure drop across the control valve was $30 \mathrm{~kg} / \mathrm{cm}^{2}$. Feed pump delivery line throttling arrangement resulted in an operating efficiency of less than $70 \%$ as against its design efficiency of $78 \%$. To avoid throttling losses and have capacity regulation, plant installed variable speed drive and realized energy savings to the tune of $552 \mathrm{~kW}$ (accounts to $10 \%$ auxiliary power consumption load).

ii. The operational condensate extraction pump (CEP) measured water flow rate is less compared to design pump capacity, but condensate water flow rate varies continuously. As well its outlet valve near de-aerator is throttled. The monitored pressure drop across the delivery control valve is $8-12 \mathrm{~kg} / \mathrm{cm}^{2}$ (pump delivery pressure $-17 \mathrm{~kg} / \mathrm{cm}^{2}$, after control valve pressure- 5 $\mathrm{kg} / \mathrm{cm} 2$, de-aerator pressure around $1 \mathrm{~kg} / \mathrm{cm}^{2}$ ). Due to the pumps delivery throttling, operating efficiency of the pump is around $45 \%$ as against design efficiency of $80 \%$. The CEP power consumption was around $146 \mathrm{~kW}$. After installation of variable speed drive and avoiding the throttling losses, measured power consumption of CEP is $64 \mathrm{~kW}$, thus resulting in power savings of $82 \mathrm{~kW}$.

iii. The installed gas booster compressor is to boost incoming natural gas pressure to $30 \mathrm{~kg} / \mathrm{cm}^{2}$ (gauge). During the initial period it was found that suction pressure drop across inlet line is on higher side compared to header line pressure. After analyzing the same, plant personal optimized the pressure by adjusting valves. After adjustment of inlet pressure, plant has recorded a reduction of $55 \mathrm{~kW}$ power drawn by booster compressor.

iv. The Air Cooled Condenser (ACC) is equipped with 14 numbers of fans, to reject heat to atmosphere. The measured power consumption of individual fans was $74-78 \mathrm{~kW}$. During the normal operation all fans will be in use. It was observed by plant personal during lower ambient dry bulb temperature (DBT) vacuum levels are on lower side. Plant incorporated the practice of 'switching-off' ACC fans (1 or 2) during favorable ambient conditions mainly during rainy season and night hours.

v. Plant has installed air cooled heat exchanger to maintain the desired low cooling water temperature in gas turbine cycle. The air cooled heat exchanger (ACHE) is equipped with 20 numbers of fans, to reject heat to atmosphere. The measured power consumption of individual fans is $6.5 \mathrm{~kW}-6.8 \mathrm{~kW}$. It was observed that the plant was able to maintain the required cooling water temperatures by switching off few fans during normal operation (except summer months). Plant has been since then monitoring ambient conditions (mainly during rainy seasons and night hours). Accordingly avoids operation of 4 to $8 \mathrm{ACHE}$ fans during favorable ambient conditions.

vi. As per the initial design of HRSG, plant has practiced continuous blowdown. The monitored blowdown quantity was around $125 \mathrm{~m}^{3}$ per day, which accounts to $3 \%$ of feed water circulation quantity. Based on quality of feed water, plant personal optimized blowdown quantity. Plant has shifted continuous blowdown practice to intermittent blowdown. The present monitored blowdown quantity is around $35 \mathrm{~m}^{3}$ per day which is equivalent to less than $1 \%$ of feed water circulation quantity. This resulted in reduction of hot well make-up water pump operating hours. Plant has also achieved decent energy savings by avoiding heating of otherwise equivalent excess makeup water.

vii. The observed single-phase voltages for lighting circuit is around $245 \mathrm{~V}$, which is on higher side compared to required levels. The reduction of voltage to lower levels $(\sim 230 \mathrm{~V})$ does not impair the ability of discharge lamps to strike though an insignificant reduction in lumen output takes place. By use of a voltage controller, reduced voltage set at $233 \mathrm{~V}$ exclusively in the lighting circuits, a saving of 8 $10 \%$ in the lighting energy consumption was realized.

viii. During the design stage plant has installed $2 \times 150$ KVA lighting transformers to pass stabilized power to plant lighting load. After commencement of plant operations, it was found that installed lighting transformers were of higher rating for plant's installed lighting load. After monitoring plant lighting load, plant has shifted complete lighting load into one lighting transformer and switched off other transformer and achieved $2 \mathrm{~kW}$ to $3 \mathrm{~kW}$ power savings by avoiding fixed losses.

\subsection{Fuel Oil Based Thermal Power Plant}

The power plant was commissioned in 1998 and is one of the world's largest fuel oil based power generation plants. The installed two stroke exhaust turbo-charged diesel engine of $50 \mathrm{MW}$ rating (each) has design engine efficiency of $48.7 \%$. The loading factor of the plant in the assessment year was reduced significantly to $40.33 \%$ compared to the baseline loading factor of $71.62 \%$. The unit wise operational details are given in table 6 .

Table 6. Unit wise comparison of operational details for baseline year and assessment year.

\begin{tabular}{|c|c|c|c|c|c|c|}
\hline & Baseline year & & & Assessment year & & \\
\hline Units & Operating load, MW & Loading factor, $\%$ & Gross generation, $\mathrm{MU}$ & Operating load, MW & Loading factor, $\%$ & Gross generation, $\mathrm{MU}$ \\
\hline Unit 1 & 45.68 & 73.15 & 962.11 & 39.50 & 42.83 & 161.18 \\
\hline Unit 2 & 45.66 & 72.70 & 956.10 & 40.30 & 32.68 & 122.96 \\
\hline Unit 3 & 45.76 & 70.81 & 931.29 & 42.90 & 36.88 & 138.79 \\
\hline Unit 4 & 45.76 & 69.71 & 916.84 & 39.30 & 46.19 & 173.84 \\
\hline Total & 182.86 & 71.62 & 3766.34 & 162.00 & 40.33 & 596.77 \\
\hline
\end{tabular}


The plant was forced to run at low PLFs as per the grid requirements. The Auxiliary consumption (APC) percentage during the assessment year was found to be higher than compared to the baseline year (3.38 to $3.92 \%)$ and was mainly due to lower plant load factor. To apply normalization plant has derived operating load \% vs. APC curve. The curve is represented in the figure 2.

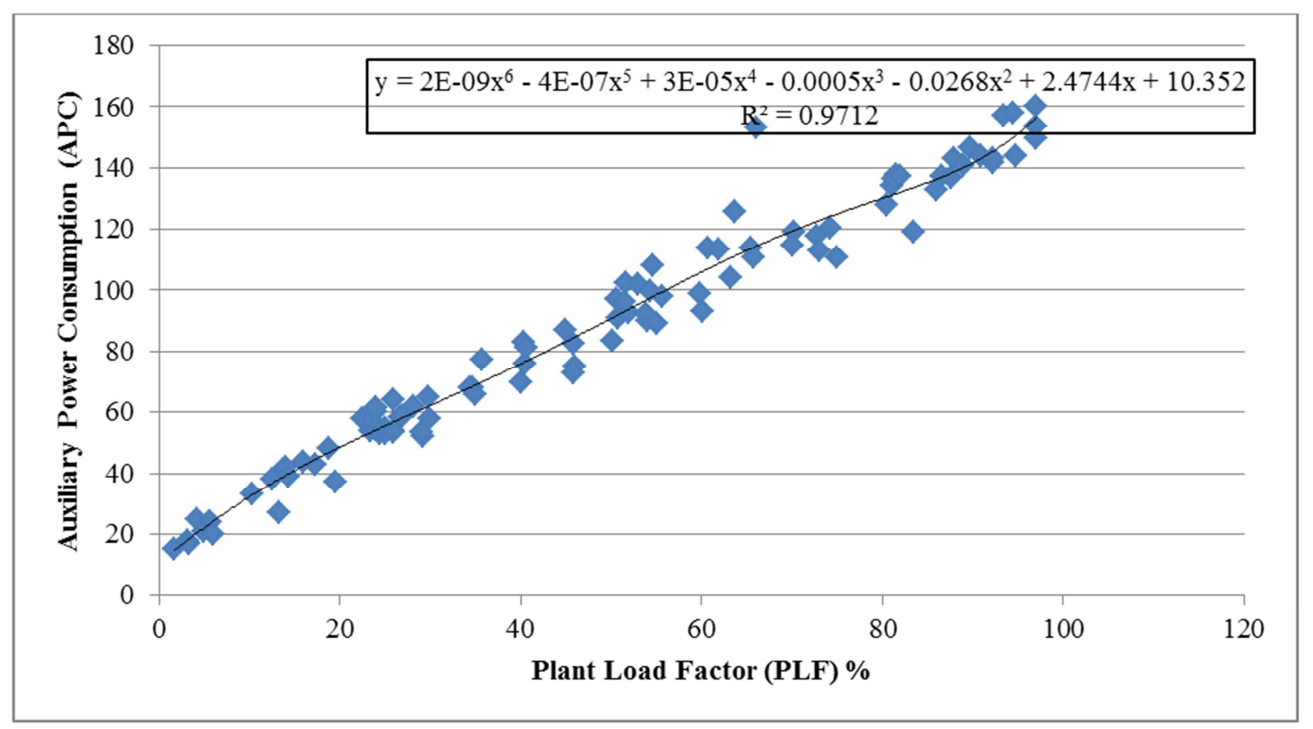

Figure 2. Auxiliary Power Consumption (APC) variation with respect to the Plant Load Factor (PLF) percentage for the DC.

The plant was maintaining heat rate below the design value of $2088 \mathrm{kcal} / \mathrm{kWh}$ even at lower PLF operations by incorporating various energy conservation measures.

i. Plant has installed 'saturated steam turbine' of $600 \mathrm{~kW}$ rating to meet its auxiliary consumption. It is mainly optimizing steam generated from waste heat recovery boilers. The investment cost towards this project is USD 0.5 million.

ii. Cooling towers fans were installed with aluminium blades. The power consumption in aluminium blades is high when compared with state-of the art aerodynamic FRP blades. Replacement of blades resulted in energy savings to the tune of $5 \%$ its power consumption without disturbing the performance of the cooling tower.

iii. Plant has installed three air compressors for air requirement of the Diesel Generators for generating air in the pressure range of 25-30 bar. It was found that even compressed air was generated at very high pressure and this high pressure is used only during DG start up. While the low pressure air is continuously required for the various applications in the plant. The estimated requirement of low pressure air was 315 $\mathrm{m}^{3} / \mathrm{h}$. To meet this demand plant has installed new compressor of relatively lower pressure capacity of 400 $\mathrm{m}^{3} / \mathrm{h}$ and realized reduction in power consumption by $40 \mathrm{~kW}$.

iv. Incorporating practices such as de-lamping/switching off of the lamps in various areas during day time was carried out. The reduction in load by de-lamping and switching off practice was $7.7 \mathrm{~kW}$.

v. Plant has replaced RO plant pumps with energy efficient pumps and realized power savings of $11 \mathrm{~kW}$.

vi. Plant has replaced high pressure MV lamps of 250 Watts with energy efficient Induction lamps of 120 Watts. The reduction in lighting load is $3.6 \mathrm{~kW}$ from introduction of Induction lamps.

\section{Results and Discussions}

Energy is one of the foremost requirements for development in any country. Every nation, developed or developing, requires energy to increase productivity. Hence increasing the energy efficiency and conservation of energy is the need of hour and is the concern for all in the power sector. Energy Conservation can be achieved by increasing the efficiency of power generation, improving the heat rate, reducing the auxiliary power consumption etc. All this has to be achieved at the least cost and without compromising on the environmental norms.

The mandated decrease in the specific energy consumption (SEC) under PAT programme has led to a decline of 4 to $5 \%$ in their SEC in 2015 as compared to the SEC values in 2012. Energy Saving Certificates (ESCerts) were issued to consumers who over-achieve the target. Out of three thermal power plants above the coal and natural gas fuel based DCs have over achieved its target, and diesel based power plant DC zilch its set target by minimizing their auxiliary power consumption. The realized ESCerts by coal and natural gas based thermal power plant DCs after normalization was 508 and 2137 respectively.

Minimizing the overall electricity generation cost will be the principle driver at least for the short and medium terms. Operating power plants will be forced to reduce operation, 
maintenance \& administration costs. One of the few opportunities for cost reduction open to operating utilities is to prevent the energy losses in the process, by effective utilization of fuel and consumables.

\section{Conclusion}

Energy used for power generation grows by $49 \%$ (based on $2.1 \%$ increase per annum) $2011-30$, and accounts for $57 \%$ of global primary energy growth. The growth of global coal consumption in power generation slows from $3.6 \%$ p.a. in $2000-10$ to $2.4 \%$ p.a. in $2011-20$ and further expected to attain $0.4 \%$ p.a. after 2020. The growth of global coal consumption in power generation slows from $3.6 \%$ p.a. in 2000-10 to $2.4 \%$ p.a. in $2011-20$ and $0.4 \%$ p.a. after 2020 . It is projected; coal's share in fuels used for power generation declines from $44 \%$ in 2020 to $39 \%$ in 2030; gas, nuclear and renewables all gain its share.

It is evident that energy efficiency initiatives in existing power generation plants should be recognized as the primary and essential step before proceeding towards any other alternatives like integration of renewable energy based power generation. PAT mechanism in India has brought tectonic changes in time bound implementation of energy efficient measures. Based on India's learning experience of PAT scheme for thermal power plants, other countries may adapt accordingly to suit their policy instruments towards achieving reduction in GHG emissions, which aids in preserving the environment both locally and also globally.

\section{Acknowledgements}

The authors thank BEE for providing opportunities to work with designated consumers for carrying out baseline studies. We would also like to thank the thermal power plants for giving opportunity to TERI for PAT scheme verification studies at the end of cycle I.

\section{References}

[1] T. Jayaraman (2016). The Paris Agreement on Climate Change: Background, Analysis and Implications. Research Gate pp7

[2] UNFCCC (2015). India's intended nationally determined contribution: Working towards Climate Justice. COP21. Paris.

[3] www.beeindia.gov.in/content/nmeee-1

[4] Montek Ahluwalia, Himanshu Gupta, Nicholas Stern., (2016). A More Sustainable Energy Strategy for India. Working Paper 328. ICRIER. New Delhi. India

[5] BP (2013). Energy outlook 2030

[6] BEE (2017). Achievements under Perform, Achieve and Trade (PAT). New Delhi, India

[7] IEA (2016). Energy Efficiency Market Report 2016. pp 70

[8] MOP (2012). Notification - Perform Achieve Trade (PAT) Mechanism. New Delhi, India

[9] Sundaresan, J., Sreekesh, S., Ramanathan (2013). Climate Change Impact on Ecosystem. pp 133

[10] Narsimha Rao G R, Rahul Raj Dusa, Senthil Kumar T., (2013). Perform Achieve Trade (PAT) Mechanism, Its Achievability and Impact on Industrial Energy Efficiency. Conference: All India Seminar on Strategies for Energy Security. Hyderabad, India

[11] BEE (2016). Perform Achieve and Trade (PAT) guidelines and normalization. New Delhi, India

[12] IPCC (2016). Intergovernmental Panel on Climate Change (IPCC). http://www.ipcc.ch/ (accessed January 2016).

[13] IPCC (2018), Intergovernmental Panel on Climate Change. Climate Change 2014 Synthesis Report, Fifth Assessment Report 